\title{
Social networks as the backbone of women's work in the Catalan Pyrenees*
}

\author{
Montserrat Pallares-Barbera ${ }^{1}$ \\ Antònia Casellas ${ }^{2}$
}

\begin{abstract}
This paper discusses how historically the accumulation of symbolic power by men produced a glass ceiling for women in the Catalan Pyrenees and how women have overcome this constraint by engaging in male-led networks, founding gender balanced networks and developing women-nurtured networks. Through semi-structured qualitative interviews and ethnographic work, the paper investigates the strategies women employed to maintain their involvement in networking activities over a 10-year period, and identifies the importance of being connected with horizontal organizations and the empowerment of sharing experiences provided by social bridge agents. The results of this research make a strong case for more inclusive and gender-aware policies in rural areas as a means to promote economic and social viability while empowering women.
\end{abstract}

Keywords. Gender inequality, symbolic power, social networks, rural development.

* We would like to acknowledge the financial support from the Spanish Ministry of Economy and Competitiveness, from grants MICINN- CSO2016-74888-C4-2-R, MICINN- CSO2013-46863-C3-2-R; and Catalonia Generalitat, from grant AGAUR- 2014 SGR 1090.

\footnotetext{
${ }^{1}$ Corresponding author. Universitat Autònoma de Barcelona. Department of Geography. e-mail: montserrat.pallares@uab.cat

${ }^{2}$ Universitat Autònoma de Barcelona. Department of Geography. e-mail: antonia.casellas@uab.cat
} 


\section{Introduction}

The glass ceiling women face in the workplace is still a big social barrier. It is found in rural and urban societies throughout the world, yet the study of women's role and visibility is under-theorized and under-developed as well as gender biased. In this article, the hidden facets of gender roles in rural society and women's engagement in social networks as a means of self-empowerment are investigated and explained. The connection between men's symbolic power and the invisibility of women's work is demonstrated. This article addresses the properties of women's networks, such as cooperation, mutual trust, bridge agents and weak network ties, as causal factors in the growing visibility of women in the modern world. The growth of women's empowerment is still a slow motion process, although the pace is picking up, but from the academic perspective there is still much research to do in order to contribute in the light of this important cause. We begin with a discussion of the theory of social networks and gender and then discuss how historically the accumulation of symbolic power by men produced the glass ceiling for women in the Catalan Pyrenees. We then examine how women have overcome this constraint by engaging in male-led networks, founding gender balanced networks and developing women-nurtured networks.

There are hidden aspects to direct perception of the inner social development of a territory, economically and culturally. Multifunctional activities on farms such as the combination of farming and tourism activities and the role of attraction to natural environments in mountain regions are beneficial to stopping deprivation and depopulation levels. The combination of economic activities within the family unit is the basis of economic development strategies in which women's work has played a crucial role. Nevertheless, in the rural community many of the most touted benefits of women's work are not perceived, and they are usually overlooked in economic studies as well. Thus, there is tension between the visible and the invisible epistemic distance or epistemic barriers (Carolan, 2006); the elements of this tension play out 
in a strongly contested debate about historic, current and authentic progress in women' status. Recent studies illustrate, among other issues, women's ability to use microcredit to suit their needs (Drolet, 2010; Kumar, 2013), how gender, race, nation and parental status influence the possible ways in which women strategize to survive or prosper in the tourism industry (Vandegrift, 2008), and how cultural norms in countries such as Mexico constrain work possibilities for women upon marriage (Brumley, 2010). A cross-sectional time-series analysis of 130 countries from 1982 to 2003 concluded that trade globalization has a generally positive influence on women's status in developing countries (Richards and Gelleny, 2007). These findings keep problematizing dominant discourses and women's work visibility and reinforce sustained debate on the causes behind them.

Traditional economic indicators such as gross domestic product (GDP) do not include the non-market economy, ignoring women's relevant contribution to economic development outside the marketplace such as work in the reproductive sphere, in the informal sector, in volunteer associations, in domestic work and within the subsistence economy (Benería et al, 2016; Benería, 2003; Boserup, 1970). In less developed economies institutional accounts typically underestimate women's work, making these countries seem poorer than they really are, as they do not capture their actual economic dynamics (Benería, 1992; Carrasco et al, 2006).

Attempts at measuring the value of women's work in the household economy go back to the early part of the twentieth century. For instance, the criterion of the "third person" (Reid, 1934) which calculates the productive value of non-market activities, identifying a price for the work done within the domestic sphere; i.e., computing the market price of cooking, caring for children, or cleaning the home. Extended analysis developed a set of criteria from the perspective of replacement (Edwards, 1989), or from that of opportunity cost. This work was criticized from a feminist perspective, in the sense that "the definition of work as waged work 
in a formally structured employment relation is based on a masculine ideal of work" p. 125 (McDowell, 1999), and based on the fact that women in the job market suffered from both horizontal and vertical segregation. In rural areas in Spain women's work and their input to local development has been important, but recognition of women's contributions has taken a long time and there have been lots of obstacles. Nevertheless, in significant ways rural women, such as those of the Catalan Pyrenees, have been able to rise up, and their experience constitutes an excellent laboratory to advance the study of the interrelation among gender relations, women's empowerment strategies and rural development (Hanson, 2010).

In the Catalan Pyrenees, women's progress has not happened quickly, and it remains precarious given the faltering economy post-2007 crisis. To expand this research and based on qualitative information obtained in the period 2002-2011, this paper provides new insights on women's involvement in rural development and how they gain empowerment through their participation in and contribution to social and cultural networks.

The analysis draws on the Bourdieu inquiry regarding symbolic capital and explores women's role in the Catalan Pyrenees, addressing how barriers prevented women from participating in the job market until recently, how women carried the burden of their hidden roles, and how they engaged in associations to regain an egalitarian role in society.

This paper shows the centrality, meaning and values of rural space and incorporates the adoption of new cultural approaches in rural studies to discuss the construction of space and place in relation to the hierarchical differences between women and men. It explores in detail the dominance of conventional notions of gender roles in the construction of rural society, and the articulation of the hidden power of men over women. The analysis tackles the issues in two parts. First, it addresses how historical cultural barriers, particularly in geographically closed mountain areas, maintained rural embedded rules to hide women's visibility. Secondly, 
we examine how women in the mountain region we studied engage with male-led networks, initiate balanced networks, and develop women-nurturing networks. The research uses lenses related to social capital to explore the strategies adopted and the process followed, and focuses on social capital "as a set of relations, processes, practices and subjectivities that affect and are affected by the contexts and spaces in which they operate" (Naughton, 2013, p. 13). The paper closes with an overview of the inquiry's key points.

\section{Social Networks and Gender}

Women's work is studied broadly from different theoretical and methodological approaches, but the picture of the work that women do, as mentioned in the introduction, is conceptually and statistically fuzzy, and most of it remains invisible for different reasons, mostly as a part of a political discursive logic of "capitalist hegemony" (Benería, 1999; Gibson-Graham, 2006, 1996). Besides these constraints, in rural societies, patriarchal structures have constructed a biased prism through which women's work is viewed.

Lack of recognition and the invisibility of women's work have been broadly identified in the gender studies literature, both in the family sphere and in the workplace (Luxton, 1997; Bryson, 1996; Folbre, 1991; Baxter, 1990; Waring, 1988; Connell and Irving, 1980; Blades, 1975). Adding to this line of research, Bourdieu's analysis of symbolic capital (1986) helps to explore the mechanisms of domination of men over women in rural areas:

According to my empirical investigations, these fundamental powers are economic capital (in its different forms), cultural capital, social capital, and symbolic capital, which is the form that the various species of capital assume when they are perceived and recognized as legitimate. Thus, agents are distributed in the overall social space, in the first dimension, according to the overall volume of capital they possess and, in the second dimension, according to the structure of their capital, that is, the relative weight 
of the different species of capital, economic and cultural, in the total volume of their assets (Bourdieu, 1989, p. 17).

Cultural capital is made up of three different elements. First, cultural capital exists as part of the habitus, and is largely created through one's upbringing. Second, the habitus is understood as schemes of perception, thought and action. In this sense, the habitus includes not only the physical, cultural and social space, but also people's beliefs and preferences. By definition, the habitus identifies how social and cultural structures and gender biases are incorporated into the subjective experiences of individuals, and how cultural capital is adopted in institutionalized forms, which are expressed via certificates and titles, among other means. Third, cultural capital is also materialized in the cultural elements that individuals know and valorize (Bourdieu and Passeron, 1977).

Social capital as a mechanism of domination and as a factor in the production of social classes has two components. First, social capital is produced by the totality of the relationships among stakeholders, but only belongs to some of them: the best positioned individuals in society. It has a multiplying effect on the economic and cultural capital of the individual who possesses it. More importantly, differences in the control of social capital explain why individuals with similar levels of economic and cultural capital attain different levels of benefits and power. Social capital is understood as a tool that reproduces class divisions by creating a mutual recognition of the different role and place that individuals should have, depending on their social class background. In this sense, social capital is an asset that is used by the dominant groups to rule others, and it is synonymous with power (DeFilippis, 2001). It is fundamental to conceptualize symbolic capital in the following manner: when the lower classes internalize a sense of duty and inferiority towards the dominant groups, the upper classes enjoy symbolic power. If the dominant group uses this power to dominate the lower classes, then this symbolic power or symbolic capital becomes symbolic violence. 
To unearth the mechanism that generates lack of visibility and legitimization of women's work, the concepts of cultural capital (habitus) and symbolic capital aid analysis of perception, invisibility and domination.

Although produced within the social realm, social capital crosses over into discussions of economic processes. As ordinary "capital," it has an exchange value and can be owned and accumulated by individuals and communities. Social relationships and networks generate resources, facilitate the circulation of information, create associations and provide services to the individual and the community. These outcomes help to create solidarity and cohesion among individuals (Franklin, 2004; Portes, 1998). The networks, norms and trust generated by social organizations facilitate cooperation and benefit the individual and the group (Putman, 2000; Putnam et al, 1993). Networks help to create collective action, while slowing down free-riding (Ostrom, 1990), and they have been identified as a source for rural development (Anderson and Bell, 2003).

Debate on whether social capital is appropriate for explaining women's empowerment brings some arguments into the analysis. There are numerous difficulties in operationalizing the concept, as it can be self-evident and circular. It is problematic to separate social capital from material goods, as "social capital may simply be another way of describing social inequalities" (Mohan and Mohan, 2002, p. 206). On the one hand, social capital has been criticized when used uncritically as a panacea to solve social problems. On the other hand, Bourdieu's ethnographic studies and feminist research have used the concept of social capital to successfully to explain local community networks in developing countries (Rankin, 2002), or to understand the outcomes of solidarity within microfinance (Bee, 2011) grounded in women's interests. Finally, if social capital is not equated with dominant policy interpretations, "embodied social capital can advance social science conceptualizations of the 
spatiality of social capital, by illuminating the importance of broader socio-spatial context and relations to the embodiment of social capital within individuals" (Holt, 2008, p. 227).

From a gender perspective, Putnam recognizes that between genders, a horizontal network aligns stakeholders into a similar category and degree of power, and facilitates cooperation and a new frame for gender interaction. In this sense, horizontal networks operate differently than vertical networks, which establish hierarchies and dependencies that hinder the promotion of civic values and development of interpersonal trust. A constraint appears nevertheless when associations are gender segregated (Norris and Inglehart, 2006).

From an economic development perspective, a region's successful accumulation of social capital results in a well-functioning economic system and a high level of political integration (Siisiäinen, 2000), where social capital is mainly developed within social networks formed by citizen activity, in voluntary associations with moral obligations and norms, along with social values based on trust, which creates reciprocity among members.

Otherwise, social capital could be defined based on its function. Social capital is the indirect result of activities conducted for other reasons (Coleman, 1988). The argument is that individuals embark on interactions because they can achieve better results that would be impossible otherwise:

It is not a single entity, but a variety of different entities, having two characteristics in common: they all consist of some aspect of a social structure, and they facilitate certain actions of individuals who are within the structure (Coleman, 1994, p. 302). 
Individuals' interactions are those that help to establish interpersonal commitments and eventually, in some circumstances, create organizations. When this mutual help is repeated across the social space within a network, it generates mutual trust.

Furthermore, the interaction between people is an interaction among resources (Lin, 2001), as every individual's response to people's needs comes from an expectation of compensation, which guides behavior and interaction. An individual's interests or preferences can be mutually coordinated and can generate balanced outcomes through the social structure of a network. This line of thought offers some explanations as to how social capital is distributed within the network and how the individual gains access to social capital. A social bridge, defined as a linkage between two individual actors in a social network, makes possible the access of resources embedded in different groups (Lin et al, 2001).

This framework of analysis for women's empowerment provides arguments, concepts and tools to explore negotiating strategies and networking activities resulting from sharing experiences within horizontal associations and the information provided by social bridge agents.

\section{The Catalan Pyrenees}

The Catalan Pyrenees is a section of Catalonia's mountainous region situated in the Northeast of Spain, a contrasting territory with a very mountainous landscape (the highest peak being 3,144 $\mathrm{m}$ in altitude), but where most of the towns and major roads as well as the majority of the population and economic activity are in the valleys (at an altitude of around $900 \mathrm{~m}$ )

(Figure 1). ${ }^{\mathrm{i}}$ Communication infrastructure improved dramatically during the 1980s, increasing the influence of Barcelona and its metropolitan area on the mountain region (Arqué et al, 1982). Yet, despite these inroads of modern culture, the community still maintains traces of a cultural structure which reproduces traditional patriarchal values, e.g., the older son, 
"l'hereu," often inherits the family property and business (which is legally sanctioned by the Catalan Legal System, “Dret Català”). If a family has only daughters, primogeniture prevails and the estate is inherited by the eldest daughter, la pubilla, the heiress (Ferrer Alòs, 2007). ${ }^{\text {ii }}$ This is a tradition of the Catalunya Vella (the Old Catalonia), in the North-Northeastern part of the region where the Roman law system has been preserved, in opposition to the Catalunya Nova (the New Catalonia) in the Southern part, where the Islamic culture established the split of the property in equal parts between siblings (Vila, 1978).

Fig.1.Catalonia's mountain region (around here)

The area experienced dramatic economic changes in the aftermath of WWII. In the 1950s large hydroelectric power plants were built to provide for the industrialized areas of Barcelona and its metropolitan region. New roads were laid down which brought natural landscape sites to tourist activity. Since the 1960s, skiing and hiking attracted seasonal tourists. In the 1980s and 1990s, with the construction of better infrastructure and ski resorts, tourism became a dominant economic sector in the region. In the twenty-first century, the CP had a high rate of second-home construction close to ski resorts (Vilagrassa, 2003). Agrarian activities diminished and family-owned micro-businesses related to tourism sprang up, often led by women. In 2001, ${ }^{\mathrm{iii}}$ more than $12 \%$ of employed women were "heads of microenterprises in firms and administration" (compared to less than 7\% for all of Catalonia) (Idescat, 2014). Women had also entered the political arena. However, as of the 2010 s, the parity policies implemented by the Spanish political parties to help increase women's involvement in polítics have had a limited impact in the Pyrenees. Women's representation in local councils, at just above 20\%, is remarkably below the rest of Catalonia and Spain (Pallarès-Blanch et al, 2014). Moreover, the analysis of the political responsibilities assigned to women who are elected further identifies a bias against them, as they are not only few in number but also 
disproportionately placed in political posts that are considered less powerful (Casellas et al, 2013).

A quantitative approach to studying the lived reality of women's work in the $\mathrm{CP}$, including both reproductive and productive spaces, has proved elusive. In this paper, qualitative analysis conducted based on lengthy fieldwork carried out over a ten year period (2002 to 2011) has provided data from 57 individuals, men and women, from the counties of Alt Urgell and Pallars Jussà. The period is relevant because it includes years of economic growth and downturn in Spain. The sample of informants/agents interviewed was drawn from personal knowledge of locals, associations and local institutional agents (Casellas, et al 2011; Pallares-Barbera et al, 2007a and b). The methodology used was snowball sampling. In terms of role-function, the sample included politicians, entrepreneurs and retirees belonging to community-based associations. Semi-structured qualitative interviews lasting between one and two hours were conducted with the interviewees in their workplaces, homes or other places of their own choosing to diminish the feeling of intrusion. All but two of the interviews were recorded and most were transcribed verbatim. A list of question prompts in plain (not academic) language was used to conduct the interview. Interviews were organized to seem informal, but they were clear in their formal objective. The key elements which were the central focus in the interview include: (1) women's work in the reproductive and productive spheres; (2) types of women's work and tasks and their skills; (3) inter-relationships, mutual trust, legitimacy; (4) participation in associations; and (5) gender differences in rolerecognition. To maintain informants' anonymous status, we used aliases for our interviewees.

\section{Symbolic power and habitus related to women's work in the Catalan Pyrenees}

Symbolic capital reflects symbolic differences between men and women, and it takes place inside the habitus. Since habitus consists of schemes of perception and thought among a 
group of people (in this case inhabitants of this region), social and cultural structures and gender biases are incorporated into the subjective experiences of individuals in the habitus. These subjective experiences internalize a sense of duty and inferiority of women to the dominant group, men, which capture symbolic power. Recognition of symbolic power is shared by "the community to then become common knowledge" (Ishihara and Pascual, 2008, p. 1551). Symbolic differences are socially accepted by women and men, and sometimes legally structured.

Symbolic capital influences how a person is perceived by others. It produces situations where a practice may be socially accepted or rejected purely on the basis of symbolic capital; e.g., in the Catalan Pyrenees men had a daily presence in village coffee shops, where they socialized and played cards. Until the 1980s, this behavior was perceived not only as an appropriate recreational activity in rural society, but also as a necessary activity for exchanging knowledge and experiences. Similar behavior by women was seen as arrogant or even morally unacceptable.

Symbolic differences exemplify the dominance of one group-men-over another group, women. The subtle issue to analyze is how it increases the invisibility of the work done by women. A man interviewed, once the organizer of activities for a group of elderly people for many years, implicitly appropriated the work done by his wife. Within his discourse the husband asserted that once his wife died he was not able to continue with these activities. The symbolic difference annotated is that his performance as organizer to a great extent was the result of his wife's contribution and support, if not leadership, but it never came out as the wife's work. He was very proud of his leadership in the group: 
... I regret to say, but while I was in charge of it (of organizing trips and social activities), everything was well organized. However, the day I gave up my commitment, everything fell apart. (Josep)

In addition to not recognizing the important role of his wife in making his group leadership possible, he mentioned later that "unconcernedly" it was only while his wife was still alive that he was capable of being the leader of the group:

... Every year in March there was a group gathering ... but once my wife died, all these events ended... (Josep)

Meanwhile, some minutes later the interviewee asserts:

... Five years ago my wife died. And then, of course, once I was left alone and helpless, I withdrew from all my activities. I stopped going to this and that ... (Josep)

He uses the expression "of course" when referring to his lack of activity once his wife died; which implies his attitude is self-evident also for the habitus which would share the same understanding. However, the role played by his wife in fostering his previous activity is invisible to him.

With the strategy to preserve their symbolic power and to maintain the glass ceiling of women's roles, men were willing to miss potential economic opportunities. Raquel, a politician, gives a powerful example of this situation by explaining the lack of success in implementing tourist policy strategies in mountainous areas in the 1970s:

From 1970-1971, the Tourist Ministry decided to give 10,000 pesetas in order to finance the rehabilitation of rural homes to make them suitable bread-and-breakfast hostels ("casas de labranza"). Then, we went to a town, a very nice town, where we had a meeting with the mayor. He said that, after studying the financing offer in depth, they 
decided not to accept it. Of course, we were puzzled, and we argued with him, trying to convince him that it was a benefit for the families in the town, that after compromising to function as hostels for two years, they had the option to quit the business and the house would retain all the improvements made to it. His answer was: "I refuse it because our wives would see the Barcelona ladies ("senyores de Barcelona") come here to spend 15 days on holiday, crocheting, sunbathing, here and there, and then, who is going to tell our wives to go and milk the cows? (Raquel)

Although this event happened in the early 1970s, it remained part of the interviewee's memory. In order to keep their patriarchal advantages, men refuse to accept a better situation, if this could give a hint to rural women of another lifestyle model. Men feel it might jeopardize their symbolic power over women.

In fact, in Spain by the 1960s, cultural values supporting the retention of symbolic power by men changed in major urban areas, but not as fast in rural areas. ${ }^{\text {iv }}$ Spanish women, especially in urban centers, played a remarkable role as agents of cultural change, participating in illegal political parties as well as in social associations. They enrolled in higher education in previously unheard of numbers, and engaged in formal market jobs. By the time of Franco's death in 1975, Spain had 79 legal organizations which had devised a collective manifesto entitled "Frente de Liberación de la Mujer, Manifiesto" ("Manifesto of the Women's Liberation Front”). Under the pressure of women's activism, Spanish political parties, then legalized, were forced to address women's policy issues, which until that time were totally absent in their agenda (Threlfall et al, 2005). The Spanish Constitution of 1978 became the basic point of reference for the equality of men and women in the new democratic Spain. From 1977 to 1981 the discriminatory laws against women were annulled. The new legislation included laws protecting women's equality in employment and marriage. Divorce 
was established in 1981, and new laws on harassment and violence against women were introduced in the mid-1980s.

But in rural areas, patriarchal values prevailed, although since the 1980s the percentage of women's work in the formal economy increased, especially in the growing agro-tourism sector. Women often became founders of hostel enterprises (García Ramón et al., 1995a and b), though many factors led to their active role frequently being neglected in the habitus (Binimelis et al, 2008; García Ramón and Baylina, 2000). Women’s increasing role in the new rural economy increased the tensions between women and the persistent patriarchal understanding in rural areas. The men showed distrust in women's performance when they had to perform an "economic" task. Raquel recalled an incident from the mid1980s that exemplified men's lack of confidence in women's performance of economic tasks:

A farmer in a meeting claimed that he needed to leave, and I said to him: "Yes, yes, you should go because you have to milk your cows" and he said: "Noooo, milking is my wife's work, but in order to give food to the cows, I better be there, because my wife gives them too much grain or too much whatever (the food) is called..." (Raquel)

The farmer does not remember the name of this specific cattle supplement, but he knows it is an economic task because he buys it. The cattle supplement has a market value; thus, the man perceives giving this food to the livestock as a specialized job requiring a "male" skilled competence which a woman cannot provide.

Simultaneously, women shared the common understanding that men were entitled to retain their symbolic power. In their role as mothers and grandmothers, they were routinely the agents that embodied and reproduced the symbolic differences through habitus. These differences were generally implicit in the patterns of children's family education in the 1950 s 
and 1960s. Rosa explained the implicit views about gender differences in her mother's dialogue about gender:

My mother had a very direct way of imposing things: "It is because I say so, because you (as a woman) have to wash dishes, because you are a girl, you have to help with the vegetable garden, and because you are a girl, you have to go grocery shopping; and if your brother wants to do it, he may, but it is not his duty." (Rosa)

Furthermore in this discourse, women were inclined to perceive their work as complementary to men's work. Although Pilar led the initiative to create a rural bed-and-breakfast hotel, she still saw her work as merely supplemental to that of her husband:

... He mainly does agricultural work; what I do is... supplementary... (Pilar)

And often women's contribution to the reproductive sphere is invisible to themselves; women's work inside the home is not seen as work:

My mother has never worked, my father worked for FECSA; ${ }^{\mathrm{v}}$ my mother, well, she was in charge of the house, children and grandparents. (Maria)

Women accepted their particular role subordinate to men and the needs of the family. Housework, which has an economic market value when externalized, is taken for granted and is perceived to have no monetary value when carried out within the family by women.

Women have contributed to transmitting the reproductive skills and the cultural way of behaving as a "woman." Maria gives this potent explanation in this sense:

When I was twelve, my grandmother told me I had to learn how to fold sheets and to be nice, because these are things that women are supposed to know... (Maria) 
Furthermore, although the situation has changed in recent decades, the glass ceiling resulted in women working at home but not outside, in market jobs; Nuria and Susan, when interviewed in 2007, recalled that in the 1960s it was common to confine women's work to inside the home:

... It was unthinkable that a woman should go out to work, totally unthinkable.... (Nuria)

And:

Here, there were no jobs for women, and that was a really big problem. I want to emphasize the fact that since I began working as a clerk, thirty-six years ago, there has been a big change... (Susan)

However, if the family economic situation required it, an exception was made for women working outside the home and doing so was accepted by society. Generally, women only participated in the paid labor force if the family was desperately poor or in genuine need of extra income:

If my mother worked outside home, it was because her family did not have enough money and... they had to put their daughter to work. Most women in similar cases became maids, clerks ... but it was not a sign of women's liberation... rather a sign of a precarious household economy. (Nuria)

Although women internalized the dominant social values and norms and reproduced the glass ceiling and the symbolic differences, and as a result undermined their self-recognition of their own capacity to lead a business or get a job, there was, nevertheless, a level of self-criticism 
or self-consciousness of the role women should have. Nuria's discourse questioning her own beliefs has an interesting inside:

I do not want to be accused of being a feminist, because I am not, but... by nature, a woman is not more (not less) intelligent (than a man) but she knows where to lead her intelligence. Is it because she has been forced to do so? I think this is the issue here. It may be that men have not realized that women can be their equal, or even they (women) might be on a higher level. (Nuria)

However, at the same time women are conscious of their key role as pillars of family structure:

If there is a problem, women will work it out. Nowadays husband and wife share problems, much more than before: when house problems were only the women's duty... but, there is this motto "If there are no men (in the family), everything goes on"... but if there are no women... well, a lot of houses have fallen apart because there were no women... when facing a problem men do not give solutions, just start wondering "what are we going to do now and how?" (Vicenta)

Nevertheless, women in the Catalan Pyrenees improved their roles' recognition over time by overcoming symbolic power and increasing their visibility. Internal mechanisms and external changes led towards another scenario, where women had a decisive role in the process.

\section{Networks and social capital: tools for women's role empowerment in the Catalan}

\section{Pyrenees}

Low percentages of participation of women in formal horizontal associations led by men were due to the explicit exclusion of female membership. However, rather than a conscious desire 
to increase women's visibility, the need to socialize and to get out of the house increased women's engagement in organizations and meetings:

Women feel freer when discussing any topic. They go out of their homes (with the purpose of) participating, (and reassuring themselves saying) I do, I have a life, and today I am going to a meeting. (Miranda)

Complex strategies enabling women to enter into male-led societies allowed women to increase their participation. Dolors, president of the Women's Confreres Association, a Catholic organization which organizes religious processions every Easter, explains the willingness of local women to participate in events that were once restricted to male members:

The whole idea came out here in the hairdresser's, with friends and clients. The first year, 25 women participated in the organization of the Procession. We had talked about the idea previously for 3 to 4 years, and we said to ourselves that that was it; ... (we knew) it was a silly thing to carry the Dolorosa wagon (the statue of the Madonna Maria Dolorosa is very heavy); it was not a religious act (for us), mostly it was about the issue of equality with men... It's hard to believe! ... (Dolors)

To achieve their goal, women went beyond orthodox taboos and habitus cultural norms. They invited male members from a traditionally ostracized group - mountain contraband smugglers - to carry the Dolorosa wagon in the procession: ${ }^{\mathrm{vi}}$

One year, it was such a laugh, I must tell you, because we couldn't find anyone to carry the wagon, and then, right, we looked for a group (of males) who were smugglers. (Dolors) 
Women were successful with their strategies to break into institutionalized male networks, and these strategies facilitated horizontal reciprocity and role recognition.

Participation of women in social networks enables them to share information which sometimes diminishes barriers and helps to incorporate them into paid work: "Once there (in the meeting), you talk about many more things" (Anna). Association activity generates a space in which conversations go well beyond the original purpose of the meeting and as an unintended consequence, invaluable interchanges of information useful for business creation occur. For instance, a European Union project provided regional funds to teach furniture restoration, and local women from different small towns took part. In this activity there was a flow of information sharing how to deal with bureaucracy to create a new business. Similar situations created a positive avenue to access information. As an indirect result, the actions taken by individuals produced social capital.

In the social sphere, the interaction of women in the networks created commitments and mutual trust that established a resource which women could draw on in times of need. For example, members that have shared experiences in social and cultural events develop personal connections which, when needed, could provide help looking after children or with family duties.

We can identify benefits and shortcomings in becoming a member of a network. Strong and enduring ties among members of rural networks constitute entry barriers to new admissions. Most times, the process of legitimization as a member of a local society stems from women's background attributes: "who brought you up, and who your friends were when you were younger" (Carmen). Women construct their position to gain access to networks through family and friendship ties: 
Local women are very close ... they keep relationships as friends with each other from childhood ... group identity ("colles" in Catalan) functions widely here. Depending on the group you grew up in, you are targeted for life. For example, who is your family? Which group did you grow up with? And which group does your husband belong to? And, then changing groups is very rare. It makes them insecure. (Carmen)

Strong ties that provide lifelong support are dominant assets for group members. Strong bonds are advantageous in providing trust, reciprocity and mutual commitment, and help insiders to disseminate information and share resources, but constitute a barrier for incoming women:

I finished my studies and I moved to Peru. When I came back to Spain I traveled around, and I decided I wanted to live in a mountain region. After a while, I realized that mountain areas are totally different from what I had imagined. I spent three and a half months painting (my flat) without interacting with anybody. Eventually, I met some people (...). (Lluïsa)

Despite an initial disadvantageous position, the weak ties represented by people like Lluïsa might nonetheless have a positive effect in the aggregate for rural society, inasmuch as they enable the creation of new ties, including with women from different circles. In that sense, the different contexts of life introduced by weak tie agents broaden the scope of women's possibilities in rural areas, open minds to new views and diversify their sphere of information and resources:

Here in the mountains, people are often pessimistic and fatalistic. I perceived a certain disdain by local people for where they lived, as if they were not happy where they were. This does not allow them to generate positive energy for their projects. Conversely, outsiders are the ones who have more projects. (Lluïsa) 
And Lluïsa offers her solution to the problem:

One of the first policy issues to implement is to find mechanisms to generate self-esteem in the local population. (Lluïsa)

Lluïsa had trouble connecting with the local community at first. But to be an outsider gave her the possibility to valorize the sense of the place, to acknowledge the disdain of her local peers. She resolved that something had to be done to change it and concluded that the help of outsiders was going to be a positive input for locals.

Conversely, women who go out of their rural area retain their status as members of their former groups, and could be transmission agents of other cultures and ways of doing things. Likewise, local bridge agents are relevant in transmitting experiences from diverse groups to locals, which could help lead to new business opportunities. While maintaining strong ties within the local structure, they bring new resources to the community resulting from personal and professional experience gained outside mountain regions:

When I came back from London, (where I went) because of my father's position (against me working at the family firm), but also from my own decision, I looked for work outside my family business. I wanted to acquire more experience and learning from other ways of working, and for this reason I looked for jobs in Andorra (...). My sister also went to France and England for two years when she finished her studies. At some point, we both came back, and we started to work in the family business with lots of enthusiasm and ideas. (Eva)

In addition, a social bridge could also be an external agent who, once accepted as a member, acquires a key position within different groups and makes the resources of each group available to the other: 
When you maintain contact with Barcelona, even if you come and stay here (mountain region), it does not imply breaking any ties with the city; I mean my day-to-day life is here (mountain region), but I did not give up to my ties with Barcelona. Over the years, I realized that I am from the city and I have a way of thinking and being that is a result of my upbringing (in the city). I do not consider myself a neo-rural or neo-hippy, it was a personal option to come and live here but with an open window to the world. (Lluïsa)

Social bridge agents might help to change cultural views about local society. A local nongovernmental organization (NGO) leader (originally from Barcelona) who had previous experience in NGO activities brought her expertise to the mountain region. She convinced a local farmer's housewife to host a girl from the Sahara, and they did so for five summers. The farmer's family, which had strong ties in the local community, shared this experience with other local people, who then hosted other Saharan children. This experience motivated farmers to travel to the original village of the Saharan girl to meet families and experience the local culture. Berta as a social bridge agent explains the complex local society mechanisms:

There was a local farmer's family that did not want to host children due to their closeminded attitude (...). Through (meeting and hosting) the girl, they went to Sahara and they opened their minds in a way that was very significant. The number of families hosting Saharan children increased from 5 to 35 families. In the whole of Catalonia, there is no antecedent of such a remarkable increase. (Berta)

Despite the entry barriers to the local society groups, once they are broken there is a vast range of positive effects for the community. Women as social bridges can link the local community with other very different cultures and resources, which can create social and economic multipliers. 


\section{Concluding remarks}

The conditions and dilemmas of everyday life in rural areas studied in this paper reveal a vital substratum of micro-relations of individuals and power exertion within roles, which when analysed as male symbolic power and cultural habitus constitutes a glass ceiling for women.

The investigation enables us to identify historical self-deception by women regarding the importance of their role and their acceptance of male-dominant social values and norms, which diminished the recognition of their own capabilities to lead a business or perform jobs in the formal economy. Despite this fact, the complexity of rural Catalan women's jobs in the reproductive and productive sphere, family duties, and community responsibilities helped them to generate the capacity to face complex problems, which opened women up to tackling challenges and devising new solutions. Analysis undertaken of women in male or female networks in the Catalan Pyrenees underlined some vital tools to increase visibility, empowering women and overcoming male symbolic power.

In the case study, gender mixed horizontal voluntary associations were traditionally uncommon. Activities carried out by the women's associations produced information interchanges which went beyond the objectives of their own activity, sometimes helping women to understand the mechanisms of business creation. Strong personal ties are the basis for member participation in women's networks. Strong bonds provide trust, reciprocity and mutual commitment, which help members to disseminate information and share resources. Entry barriers preventing outsiders from benefiting from the network produce weak ties, which might also have a positive effect, since they enable women to connect with different circles, broaden contexts and scopes, and diversify their sphere of information and resources. The study further identifies the importance of social bridges as local agents who maintain strong ties within the local structure and have experiences from other environments and jobs. 
Social bridge agents bring new resources to the local community derived from their personal and professional experience outside the mountain regions. As agents in key positions within a social network which tie together different groups, they can, over time, promote growth of the resources unifying the information from both groups and make it accessible to individuals.

The study highlights the importance of outsiders' contact with local women's networks, and emphasizes that achievements of women in rural areas are material, enduring and creating the conditions to be replicated in the future.

From a policy perspective, inclusive, gender-aware policies and services should recognize women's often-hidden contributions, which include discipline, initiative, strength, ability to multi-task and ability to adapt to changing conditions. In this sense, the paper's findings advocate for policy to foster mixed gender voluntary associations as a tool to increase interaction and experience sharing between genders. Horizontal voluntary organizations are important mechanisms for rural areas, for which they assert rules of reciprocity, facilitate communication and improve information flow among members, which enables the recognition of work and transmission of prestige between genders. Ultimately, as voluntary associations might facilitate cooperation among network members, the value of mixed gender voluntary associations in rural areas creates a milieu of more egalitarian status or power between genders.

i

The Catalan Pyrenees are defined by the Catalan Government and formed by the Alt Pirineu Aran region (5,685.8 km2 with 76,287 inhabitants (2008 census)), distributed in 77 municipalities and 6 counties (Alt Urgell, Alta Ribagorça, Cerdanya, Pallars Jussà, Pallars Sobirà, and Vall d'Aran) and the Low Pyrenees areas which include the counties of Berguedà, Garrotxa, Ripollès, and Solsonès (3,451.2 km2 and 85 municipalities) (Parlament de Catalunya, law 2/1983). www.parlament.cat/activitat/llei/c2_1983.doc. 

daughter was supposed to make a good marriage and did not have much inheritance from her family, just the dowry, la dot.

iii Last comprehensive census data.

iv Spain's religious tradition and almost forty years of political dictatorship played an important role in gender relations. Under the theme of Marianismo (Virgin Mary as a symbol of what a woman should be), gender roles in Spain reinforced the pattern that linked women to family and community obligations, while men dominated the public sphere (Englander et al, 2012; Preston, 1996). The evolution of this stereotyped gender pattern adapted to the country's complex and idiosyncratic 20th century political history generated radical and efficient grassroots movements supporting women's mobilization and emancipation. During the Spanish Second Republic (1931-1939), the Mujeres Libres movement, closely linked to anarchist ideology, mobilized over 20,000 women into an organized network to strive for community, education, and equality (Ackelsberg, 2004), which resulted in the creation of unique women's rights policies; subsequently, they were lost during Franco's dictatorship (1939 to 1975). The right-wing authoritarian regime's laws discriminated strongly against women. For more than a third of a century a wife, without her husband's approval ("permiso marital"), was banned from almost all economic activities, including employment, ownership of property, or even travel away from home (Benería, 1977). Women were ostracized, as both public laws and church regulations enforced a set of cultural rules aimed at preserving the traditional role of the family and the "right" place for women at home.

v Fuerzas Eléctricas de Catalunya Sociedad Anónima.

vi Border smuggling is a common practice in the Pyrenees. Catalan mountainous regions are adjacent to Andorra and France. In the Spanish Civil War (1936-1939) political refugees used hidden paths to escape persecution, and the reverse pattern took place during the Second War World. Since then, and with varying intensity over the years, these routes have been actively used to smuggle contraband between countries, mainly from Andorra to Spain. 


\section{References}

Ackelsberg M (2004) Free women of Spain: anarchism and the struggle for the emancipation of women. Chico: AK Press.

Anderson C and Bell M (2003) The devil of social capital: a dilemma of American rural sociology. In: Cloke P (Ed). Country visions. Essex: Pearson Educational Limited: 232-244.

Arqué M, Garcia A and Mateu X (1982) La penetració del capitalisme a les comarques de l'Alt Pirineu. Documents d'Anàlisi Geogràfica 1: 9-67.

Baxter J (1990) Domestic labour: issues and studies. Labour and Industry 3(1): 112-145.

Bee B (2011) Gender, solidarity and the paradox of microfinance: reflexions from Bolivia. Gender, Place \& Culture: A Journal of Feminist Geography 18(1): 23-43.

Benería L, Berik G and Floro M S Eds (2016) Gender, development and globalization. Economics as if all people mattered. London: Routledge.

Benería L (2003) Gender, development and globalization. Economics as if all people mattered. London: Routledge.

Benería L (1999) Globalization, gender and the Davos man. Feminist Economics 5(3): 61-83.

Benería L (1992) Accounting for women's work: the progress of two decades. World Development 20(11): 1548.

Benería L (1977) Mujer, economía y patriarcado durante la España franquista. Barcelona: Anagrama.

Binimelis R, Bosh M and Herrero A (2008) A sol i serena: dones, món rural i pagesia. Barcelona: Institut Català de les Dones.

Blades D (1975) Non-monetary activities in the national accounts of developing countries. Paris: OECD. 
Boserup E (1970) Woman's role in economic development. New York: St. Martin's Press: 283.

Bourdieu P (1989) Social space and symbolic power. Sociological Theory 7(1): 14-25.

Bourdieu P (1986) The forms of capital. In: Richardson J (Ed) Handbook of theory and research for the sociology of education. New York: Greenwood Press: 241-258.

Bourdieu P and Passeron J C (1977) Reproduction in education, society and culture. London: Sage.

Brumley K M (2010) Gender, class, and work: the complex impacts of globalization. In: Texler Segal M (Ed) Interactions and intersections of gendered bodies at work, at home, and at play, Advances in Gender Research 14. Bingley: Emerald Group Publishing Limited: 95119.

Bryson L (1996) Revaluating the household economy. Women's Studies International Forum 19(3): 207-219.

Carolan M S (2006) Do you see what I see? Examining the epistemic barriers to sustainable agriculture. Rural Sociology 71(2): 232-260.

Carrasco C et al (2006) Estadístiques sota sospita. Proposta de nous indicadors des de l'experiència femenina. Barcelona: Institut Català de les Dones.

Casellas A, Tulla A, Vera A and Pallarès-Blanch M (2013) Gobernanza local y espacio rural: un análisis territorial desde la perspectiva de género. Boletín de la Asociación de Geógrafos Españoles 62: 379-402.

Casellas A, Tulla A, Vera Martin A, Pallarès Blanch M, Pallares-Barbera M (2011) Desenvolupament econòmic i participació de les dones al govern local de muntanya. Barcelona: Institut Català de les Dones. Generalitat de Catalunya.

Coleman J S (1994) Foundations of social theory. Cambridge: The Belknap Press of Harvard University Press. 
Coleman J S (1988) Social capital in the creation of human capital. American Journal of Sociology 94: 95-121.

DeFilippis J (2001) The myth of social capital in community development. Housing Policy Debate 12: 781-806.

Connell R W and Irving T H (1980) Class structure in Australian history. Melbourne: Longmann Cheshire.

Drolet J (2010) Feminist perspectives in development: implications for women and microcredit. Affilia 25(3): 212-223.

Edwards M (1989) Household productive activities. In: Ironmonger D (Ed) Household work: productive activities, women and income in the household economy. Sydney: Allen \& Unwin.

Englander K, Yáñez C, and Barney X (2012) Doing science within a culture of machismo and Marianismo. Journal of International Women's Studies 13(3): 65-85.

Ferrer Alòs Ll (2007) Hereus, pubilles i cabalers. El sistema d'hereu a Catalunya. Catarroja: Afers.

Folbre N (1991) The unproductive housewife: her evolution in nineteenth-century economic thought. Signs 16(3): 463-484.

Franklin J (Ed) (2004) Politics, trust and networks: social capital in critical perspective. London: London South Bank University.

García Ramón M D and Baylina M (Eds) (2000) El nuevo papel de las mujeres en el desarrollo social. Vilassar de Mar: Oikos-Tau.

García Ramón M D, Cruz Villalón J, Salamanca Serra I and Vilariño Pérez M (1995a) Mujer y agricultura en España: género, trabajo y contexto regional. Vilassar de Mar: Oikos-Tau.

García Ramón M D, Canoves G and Valdovinos, N (1995b) Farm tourism, gender and the environment in Spain. Annals of Tourism Research 22(2): 267-282. 
Gibson-Graham J K (2006) A postcapitalist politics. Minneapolis: University of Minnesota Press.

Gibson-Graham J K (1996) The end of capitalism (as we knew it): a feminist critique of political economy. Oxford: Blackwell.

Hanson S (2010) Gender and mobility: new approaches for informing sustainability. Gender, Place and Culture, 17 (1): 5-23.

Holt L (2008) Embodied social capital and geographic perspectives: performing the habitus. Progress in Human Geography 32(2): 227-248.

Idescat, http://www.idescat.cat/ (2014) (Accessed 07/05/2014).

Ishihara H and Pascual U (2008) Social capital in community level environmental governance: a critique. Ecological Economics 68 (5): 1549-1562.

Kumar D, Hossain A and Gope M C (2013) Role of Micro Credit Program in Empowering Rural Women in Bangladesh: A Study on Grameen Bank Bangladesh Limited Asian Business Review, 3 (4): 114-120.

Lin N (2001) Social capital - A theory of social structure and action. Cambridge, UK:

Cambridge University Press.

Lin N, Cook K and Burt R S (Eds) (2001) Social capital. New York: Aldine de Gruyter.

Luxton M (1997) The UN, women, and household labour: measuring and valuing unpaid work. Women's International Studies Forum 20(3): 431-439.

McDowell L (1999) Gender, identity \& place. Understanding feminist geographies.

Minneapolis: University of Minnesota Press.

Mohan G and Mohan J (2002) Placing social capital. Progress in Human Geography 26(2): 191-210. 
Naughton L (2013) Geographical narratives of social capital: telling different stories about the socio-economy with context, space, place, power and agency. Progress in Human Geography 38(3): 3-21.

Norris P and Inglehart R (2006) Gendering social capital: bowling in women's leagues? In O’Neill B and Gidengil E (Eds). Gender and social capital. New York: Routledge: 73-98.

Ostrom E (1990) Governing the commons. New York: Cambridge University Press.

Pallares-Barbera M, Pallarès-Blanch M and Tulla A (2007a) Visibilitat, lideratge i distorsions de rol en les dones rurals: capital social i governança. Barcelona: Institut Català de les Dones, Generalitat de Catalunya.

Pallares-Barbera M, Pallarès-Blanch M and Tulla A F (2007b) Capital social i treball de les dones als Pirineus. El cas de l'Alt Urgell. Report. Barcelona: Institut Català de les Dones. Generalitat de Catalunya.

Pallarès-Blanch M, Tulla A F, Casellas A and Vera A (2014) Entre premios y recortes: el zigzagueante proceso de empoderamiento de las mujeres rurales. Biblio 3 W. Revista Bibliográfica de Geografía y Ciencias Sociales (XIX):1057 <http://www.ub.es/geocrit/b3w1057.htm>

Portes A (1998) Social capital: Its origins and applications in modern sociology. Annual Sociology 24: 1-24.

Preston D (Ed) (1996) Latin American development: geographical perspectives. Essex: Longman.

Putnam R (2000) Bowling alone. The collapse and revival of American community. New York: Simon \& Shuster.

Putnam R, Leonardi R and Nanetti R Y (1993) What makes democracy work? National Civic Review 82 (2): 101-108. 
Rankin K N (2002) Social capital, microfinance, and the politics of development. Feminist Economics 8(1): 1-24.

Reid M (1934) The economics of household production. New York: John Wiley and Sons.

Richards D and Gelleny R (2007) Women's status and economic globalization. International Studies Quarterly 51: 855-876.

Siisiäinen M (2000) Social capital, power and the third sector. In: Siisiäinen M, Kinnunen P and Hietanen E (Eds). The third sector in Finland. Helsinki: STKL: 3-25.

Threlfall M, Cousins C and Valiente C (2005) Gendering Spanish Democracy. London: Routledge.

Vandegrift D (2008) This isn't Paradise-I Work Here: Global Restructuring, the Tourism Industry, and Women Workers in Caribbean Costa Rica. Gender \& Society 22(6): 778-798.

Vila P (1978) Aspectes geogràfics de Catalunya. Barcelona: Curial.

Vilagrassa J (2003) L'Alt Pirineu i Aran, entre l'eficiència econòmica i la sostenibilitat. Papers, Regió Metropolitana de Barcelona 39: 127-149.

Waring M (1988) Counting for nothing: what men value and what women are worth. Wellington: Allen \& Unwin. 
Figure 1. Catalonia's Mountain Regions

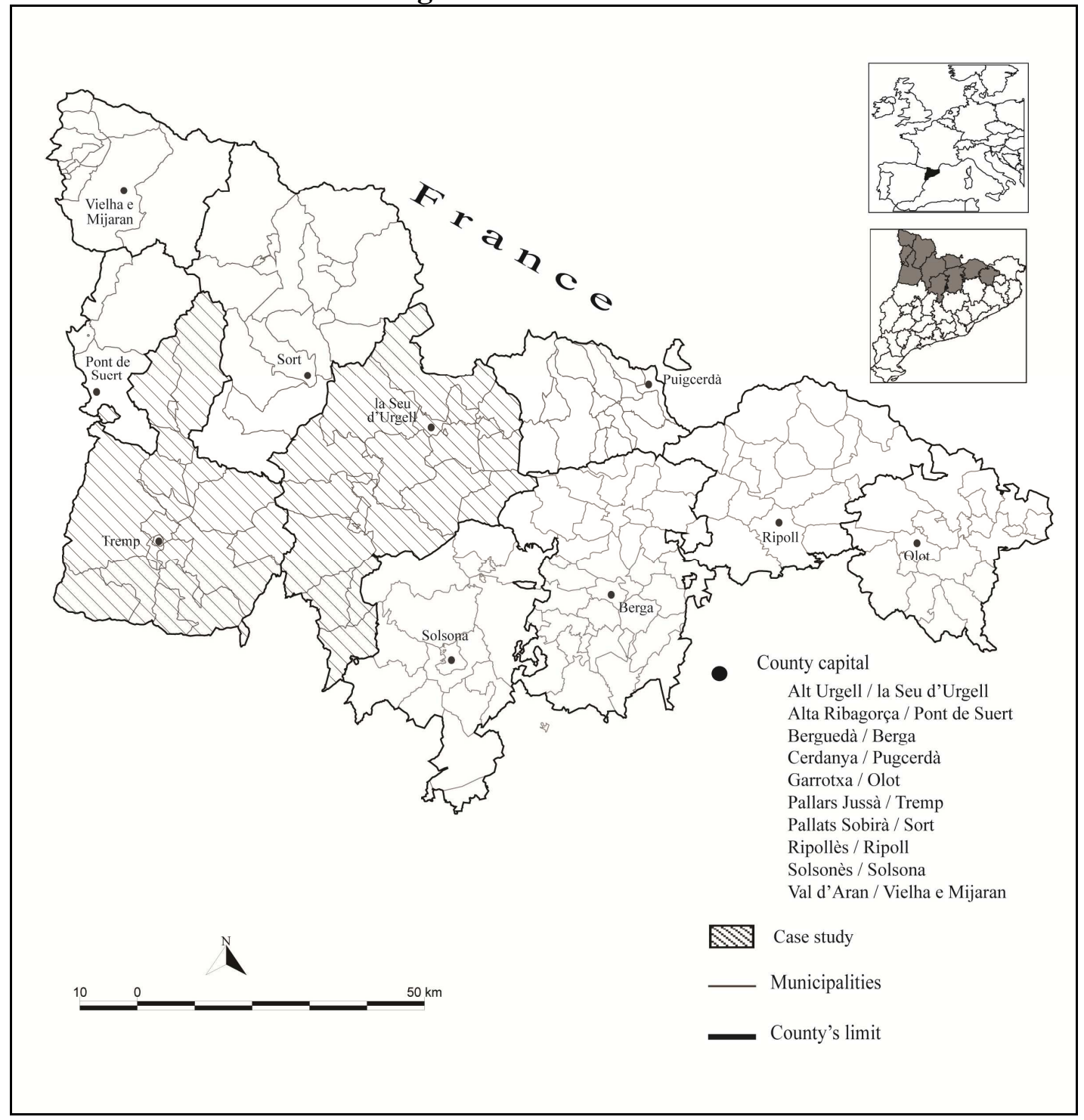

Source: Elaborated by authors. 